\title{
Feral Cats: Parasitic Reservoirs in Our Zoos?
}

\section{Thalyta Ananias Lima1,2, Paula Andrea Borges Salgado², Carolina Romeiro Fernandes Chagas², Patrícia Locosque Ramos², Edson Aparecido Adrianoํㅜ, Irys Hany Lima Gonzalez ${ }^{2 *}$}

\author{
${ }^{1}$ Department of Biological Science, São Paulo Federal University (UNIFESP), Diadema, Brazil \\ ${ }^{2}$ Applied Research Department, São Paulo Zoological Park Foundation, São Paulo, Brazil \\ Email: *irys_lima@hotmail.com
}

How to cite this paper: Lima, T.A., Salgado, P.A.B., Chagas, C.R.F., Ramos, P.L., Adriano, E.A. and Gonzalez, I.H.L. (2020) Feral Cats: Parasitic Reservoirs in Our Zoos? Open Journal of Veterinary Medicine, 10, 126-138.

https://doi.org/10.4236/ojvm.2020.108011

Received: June 5, 2020

Accepted: August 10, 2020

Published: August 13, 2020

Copyright $\odot 2020$ by author(s) and Scientific Research Publishing Inc. This work is licensed under the Creative Commons Attribution International License (CC BY 4.0).

http://creativecommons.org/licenses/by/4.0/

\begin{abstract}
Up until the recent past, zoos served limited function, primarily existing for entertainment value. Today's zoos, however, are serving many roles, chief among them: species conservation of captive animals. The biggest zoo in Brazil, São Paulo Zoological Park Foundation, has among its 2000 animals and many species of wild cats. The presence of domestic cats living freely in zoos is common and can be a source of spreading disease. The aim of this study was to verify the variety and prevalence of parasites found in the feces of felids (feral and wild) living in the São Paulo Zoo. The results of this parasitological analysis have been obtained from the laboratory of clinical analysis and correspond to the 4-year period beginning January/2009 and ending December/2012. Eight species of parasites were identified in the feces of captive wild cats and three in the feces of feral cats. For those captives, Toxocara cati (7.95\%) had the highest prevalence, followed by Toxascaris leonina $(7.58 \%)$, Isospora sp. (2.03\%), Hymenolepis nana (0.92\%), Eimeria sp., Giardia sp. and Blastocystis sp. (0.37\% each) and Ascaris sp. (0.18\%). Among the feral cats, we found Toxocara cati (59.26\%), Giardia sp. (22.22\%) and Isospora sp. (11.11\%). For the captive group, we also distinguished natives from exotic species, finding native species to be more frequently parasitized than the exotic ones. Key to our findings, though, was the fact that a few parasite species were found among all groups of felids, specifically (Toxocara cati, Giardia sp. and Isospora sp). Further research is needed, however, to confirm that transmission of these parasites is occurring between and among these groups.
\end{abstract}

\section{Keywords}

Enteroparasites, Felids, Felis catus, Toxocara cati, Wild Animals

\section{Introduction}

Frequent discussions involving zoos are due to the origin of these institutions, 
which is directly linked to different human attitudes towards animals [1]. The basic purpose of zoos was to expose exotic species to society as a source of entertainment, but nowadays they have as main goals: species conservation, scientific research and entertainment [2]. In Brazil, the history of zoos begins around 1882 in the city of Belém where the first zoo was created, (Pará, Brazil). Created in 1957 and inaugurated in 1958, the São Paulo Zoological Institute is an important Brazilian zoo; in 1959, it became the São Paulo Zoological Park Foundation (FPZSP), with legal authority, autonomy and defined objectives [3]. In addition to providing entertainment, encouraging research and developing environmental awareness, FPZSP also develops and acts in in-situ and ex-situ species conservation projects [4].

Among the animals in the FPZSP, there exists a large diversity of species, and one of the largest groups are felids (Mammalia) [4] [5] [6]. Felids are members of Felidae and have, in general, nocturnal and solitary habits, being intolerant to other adults of the same sex [7] [8]. When kept in captivity, these species often exhibit maladaptive, or locomotive stereotyped behavior (repetitive and without apparent function), owing to small enclosures and limited environmental interaction [6] [9].

Being top-chain predators, they also may be affected by anthropic changes in the environment, making them vulnerable. In this way, all felids present some degree of extinction threat according to the International Union for Conservation of Nature (IUCN) [8] [10].

Zoos help in the prevention of wild species rapid extinction, as they are considered great ex-situ breeding centers and have species conservation as one of their main goals. Indeed, studies with captive felids are easier to perform than with wild animals and can play an important role in the conservation of these animals [9] [11].

Common to zoos, felids can be divided into two groups: exotic and native felid species, dependent on the location of the institution and animal species. Exotic felids kept in FPZSP are native to Africa and Asia; native species are found throughout Brazil [12].

Another species of felid that is common in the São Paulo Zoo is the feral domestic cat (Felis catus). These animals organize themselves in groups, finding the zoo environment resourceful as a means for scouring food and providing physical structure for shelter; these qualities make the zoo environment ideal for the development of large colonies and all of these facts contribute to increasing the possibility of pathogen transmission due to the proximity of wild captive animals and feral domestic cats [13].

The biggest concern related to the presence of feral domestic cats in zoos is related to transmission of felid retroviruses, toxoplasmosis and mycoplasmosis, but enteroparasites are also important, due primarily to their zoonotic potential [13]-[18]. In Brazil, many studies have reported infections due to gastrointestinal parasites in feral cats, resulting in the disease that has the potential to be 
transmitted to a nearby captive population [14] [15] [19]-[25].

Several species that parasitize cats may have high zoonotic potential. Although the majority of parasitic zoonoses are not fatal in humans, they can cause unpleasant clinical symptoms and must be combated [15]. However, it must be taken into account that some serious infections are caused by parasites commonly found in cats, as is the case of toxocariasis. This disease is caused by the nematodes Toxocara canis (which has the domestic dog as its definitive host) and Toxocara cati, whose definitive host is the domestic or wild cat. Although they can survive for years in animals without causing clinical changes, very intense infections can lead to diarrhea, dehydration, growth retardation (for puppies) and even death [26]. Other parasites such as Ancylostoma sp., Giardia sp. and Cryptosporidium sp. they can also cause diseases and deserve more attention, since they have been previously described in Brazil and in other parts of the world because they parasitize domestic cats [14] [15] [19]-[25] and wild felids [27] [28] [29] [30] [31]. In Brazil, much has been studied in regards to the gastrointestinal parasites that most affect stray domestic cats and the possible diseases that can be transmitted to the population, [19] [20] [22] [23] [24] as well as data on enteroparasites present in stray and domestic cats have also been compared [14] [15] [21] [24] [25].

With regard to felids and captive animals, research has already been carried out in several parts of the world, such as Tanzania [30], India [17] [18] [31] [32], Malaysia [28], Iran [33] [34], Italy [35], Spain [36] and Zambia [37], which demonstrates the importance of this subject. However, little is known about the prevalence of enteroparasites in Brazil [27] [29] [38], indicating the need for more research in this area in the country.

To contribute to the knowledge of gastrointestinal parasites affecting wild felids in captivity in the São Paulo Zoo, the present study intends to bring the coproparasitological profile of felid species kept in the Foundation, considering feral cats $(F$. catus) as a possible reservoir.

\section{Material and Methods}

\subsection{Samples}

The present study analyzed results of coproparasitological exams from 13 species of Felidae kept in captivity and from feral domestic cats that are circulating in São Paulo Zoo; this was performed over a period of 4 years beginning January/2009 and ending December/2012, and included all samples received by the Clinical Analysis Laboratory. As a general protocol followed by this institution, fresh fecal samples were obtained from the animal enclosure, using clean, uncontaminated material and all samples were processed through the following techniques: direct method, fecal flotation with sodium chlorite solution and fecal sedimentation. The smears were analyzed under optical microscopy and the parasite identification was performed according to morphological characteristics using the literature available [39] [40]. Captive species were divided into native 
and exotic, depending on the current distribution and native location of studied species, according to IUCN Red List of Threatened Species online database.

\subsection{Data Analysis}

This retrospective study analyzed 587 results of processed samples from 13 captive species and 27 results from feral cats. To make the survey more accurate and safer, only the data that presented parasite identification in the minimum level of genus was used. This resulted in a total of 541 samples of captive animals and 27 of feral domestic cats.

After initial screening, three different types of analysis were performed: comparison between results of native and exotic felids; prevalence of infections in feral domestic cats and analyses of all felid captive species in the FPZSP. The analyses were performed quantitatively, based on the percentage of samples that showed positive results for a given parasite.

These analyses allowed us to identify which parasites were most frequently found in each group (native felids, exotic felids, captive felids in general and wandering domestic cats), compare the results among these groups and identify the parasite that is most commonly found in each species.

\section{Results}

\subsection{Captive Wild Felids}

Among 541 results analysed, 105 (19.41\%) were positive for at least one parasite. Mixed infections were found in two samples from Leopardus colocolo and in both of them protozoa Isospora sp. and Eimeria sp. were associated. Samples indicating the presence of helminths corresponded to $16.63 \%$ (90/541), while $3.14 \%$ (17/541) were positive for protozoans. The results show that helminth infections are more frequent than protozoan infections in both native, $14.78 \%$ (51/345), and exotic species, 19.9\% (39/196).

Considering felids in general, Toxocara cati was the helminth with the highest prevalence with 43 (7.95\%) positive samples, followed by Toxascaris leonina with $41(7.58 \%)$ positive samples, Hymenolepis nana with five $(0.92 \%)$, and $A s$ caris sp. with only one $(0.18 \%)$. Among protozoans, Isospora sp. was the most common, with 11 (2.03\%) positive samples; Eimeria sp., Giardia sp. and Blastocystis sp. were the second most frequent with two $(0.37 \%)$ positive samples each (Table 1).

From the 541 results analyzed, $345(63.77 \%)$ were referring to the native species, while 196 (36.22\%) were related to the exotic species.

Considering only native species samples, $80.87 \%$ (279/345) were negative and $19.13 \%(66 / 345)$ were positive for any parasite. The most frequent parasite found in this group was T. cati, found in $43(12.46 \%)$ samples, followed by Isopora sp. (3.19\%), T. leonina (1.74\%), Eimeria sp. (0.58\%), Giardia sp. (0.58\%), Blastocystis sp. $(0.58 \%)$ and $H$. nana (0.58\%) (Table 2$)$. Considering only positive results, Toxocara cati was found in $65.15 \%$ of the samples, followed by Isopora sp. 
Table 1. Prevalence of the different parasites identified in samples of felids of the FPZSP.

\begin{tabular}{llcc}
\hline & Parasites & Number of positive cases & Prevalence (\%) \\
\hline Protozoa & Isospora sp. & 11 & 2.03 \\
& Eimeria sp. & 2 & 0.37 \\
& Giardia sp. & 2 & 0.37 \\
Helminths & Blastocystis sp. & 2 & 0.37 \\
& Toxocara cati & 43 & 7.95 \\
& Toxascaris leonina & 41 & 7.58 \\
& Hymenolepis nana & 5 & 0.92 \\
& Ascaris sp. & 1 & 0.18
\end{tabular}

Table 2. Occurrence of enteroparasites in native and exotic species present at FPZSP.

\begin{tabular}{|c|c|c|c|c|c|c|c|c|c|}
\hline & $\begin{array}{l}\text { Analysed } \\
\text { samples }\end{array}$ & $\begin{array}{c}\text { Toxocara } \\
\text { cati, } \\
\text { n (\%) }\end{array}$ & $\begin{array}{c}\text { Isospora } \\
\text { sp., } \\
\text { n (\%) }\end{array}$ & $\begin{array}{c}\text { Toxascaris } \\
\text { leonina, } \\
\text { n (\%) }\end{array}$ & $\begin{array}{c}\text { Hymenolepis } \\
\text { nana, } \\
\text { n (\%) }\end{array}$ & $\begin{array}{c}\text { Eimeria } \\
\text { sp., } \\
\text { n (\%) }\end{array}$ & $\begin{array}{c}\text { Giardia } \\
\text { sp., } \\
\text { n (\%) }\end{array}$ & $\begin{array}{c}\text { Blastocystis } \\
\text { sp., } \\
\text { n (\%) }\end{array}$ & $\begin{array}{c}\text { Ascaris } \\
\text { sp., } \\
\text { n (\%) }\end{array}$ \\
\hline \multicolumn{10}{|l|}{$\underline{\text { Native felids }}$} \\
\hline Pampas cat (Leopardus colocolo) & 28 & $2(7.14)$ & $4(14.28)$ & - & - & $2(7.14)$ & $1(3.57)$ & - & - \\
\hline Geoffroy's cat (Leopardus geoffroyi) & 95 & $13(13.68)$ & - & - & - & - & $1(1.05)$ & $2(2.1)$ & - \\
\hline Ocelot (Leopardus pardalis) & 1 & - & - & - & - & - & - & - & - \\
\hline Northern tiger cat (Leopardus tigrinus) & 122 & $17(13.93)$ & $5(4.10)$ & $2(1.64)$ & - & - & - & - & - \\
\hline Margay (Leopardus wiedii) & 37 & - & - & - & $2(5.40)$ & - & - & - & - \\
\hline Jaguar (Panthera onca) & 18 & - & - & - & - & - & - & - & - \\
\hline Puma (Puma concolor) & 15 & $9(60.0)$ & $1(6.66)$ & - & - & - & - & - & - \\
\hline Jaguarundi (Puma yagouaroundi) & 29 & $2(6.9)$ & $1(3.45)$ & $4(13.79)$ & - & - & - & - & - \\
\hline Total (native felids) & 345 & $43(12.46)$ & $11(3.19)$ & $6(1.74)$ & $2(0.58)$ & $2(0.58)$ & $2(0.58)$ & $2(0.58)$ & - \\
\hline \multicolumn{10}{|l|}{$\underline{\text { Exotic felids }}$} \\
\hline Serval (Leptailurus serval) & 54 & - & - & - & $3(5.55)$ & - & - & - & - \\
\hline Lion (Panthera leo) & 53 & - & - & $30(56.6)$ & - & - & - & - & - \\
\hline Leopard (Panthera pardus mela) & 2 & - & - & - & - & - & - & - & - \\
\hline Amur tiger (Panthera tigris altaica) & 65 & - & - & - & - & - & - & - & - \\
\hline Bengal tiger (Panthera tigris tigris) & 22 & - & - & $5(22.73)$ & - & - & - & - & $1(4.54)$ \\
\hline Total (exotic felids) & 196 & - & - & $35(17.86)$ & $3(1.53)$ & - & - & - & $1(0.51)$ \\
\hline
\end{tabular}

$\mathrm{n}=$ number of positive samples.

(16.67\%), T. leonina (9.09\%), Eimeria sp. (3.03\%), Giardia sp. (3.03\%), Blastocystis sp. (3.03\%) and $H$. nana $(3.03 \%)$.

All native felids were positive for at least one parasite, except for ocelot (Leopardus pardalis) and jaguar (Panthera onca), which had negative results. The only parasite found in margay (Leopardus wiedii) was the helminth belonging to the class Cestoda, H. nana. The protozoans Eimeria sp. and Blastocystis sp. were 
identified only in pampas cat (Leopardus colocolo) and geoffroyi's cat (Leopardus geoffroyi) samples, respectively (Table 2).

Samples related to exotic species, from 196 results analyzed, 157 (80.1\%) were negative for the presence of parasites and 39 (19.9\%) were positive. In this group, Toxocara leonina had the highest prevalence, found in $35(17.86 \%)$ samples. Hymenolpis nana was the second most prevalent with $1.53 \%$ (3/196), followed by Ascaris sp. found only in one sample (0.51\%) (Table 2). Considering positive samples, Toxocara leonina was the most common parasite (89.74\%), followed by $H$. nana with $7.69 \%$ and Ascaris sp. with $2.56 \%$. All samples were negative for protozoan and T. cati infections. Although the prevalence was high for T. leonina, this parasite was found in only two species, Panthera leo and Panthera tigris tigris. Hymenolepis nana and Ascaris sp. were identified in only in Leopardus serval and $P$. tigris, respectively. All samples of leopard (Panthera pardus mela) and amur tiger ( $P$. tigris altaica) were negative (Table 2).

Among all analyzed samples, $T$. cati had the highest prevalence (7.95\%), where it was identified in 43 samples. The second most common was T. leonina found in 35 samples (7.58\%), followed by Isospora sp. with prevalence of 2.03\% (11/541), H. nana found in five samples (0.92\%), Eimeria sp., Giardia sp. and Blastocystis sp. found in two samples and with a prevalence of $0.37 \%$ each and Ascaris sp. identified in only one sample (0.18\%) (Table 1$)$. Considering only positive samples, $T$. cati had a prevalence of $40.95 \%$. The second most common was T. leonina (39.05\%), followed by Isospora sp. (10.48\%), H. nana (4.76\%), Eimeria sp., Giardia sp. and Blastocystis sp. (1.90\% each) and Ascaris sp. (0.95\%).

Toxocara cati was the most common parasite in this study, but it was present only in native animal samples, while Ascaris sp. appeared only in exotic animals. Some species did not have parasite infections, these were: ocelot (L. pardalis), jaguar (P. onca), leopard (P. pardus mela) and amur tiger (P. tigris altaica) (Table 2).

\subsection{Feral Cat (Felis catus)}

Twenty-seven coproparasitological exam results were analyzed, of which seven (25.93\%) showed negative results and twenty $(74.07 \%)$ were shown to be positive for at least one parasite species. Mixed infections were identified in six samples (22.22\%) and the most frequent association was between T. cati and Giardia sp. in four samples (14.81\%) (Table 3).

Samples from this group showed that infections by helminths were more common than for protozoans. Helminths were present in 16 samples (59.26\%) and protozoans in nine (33.33\%) (Table 3). Three different parasite species were identified: $T$. cati, in 16 samples (59.26\%), followed by Giardia sp. in six samples $(22.22 \%)$ and Isospora sp. in three samples (11.11\%) (Table 3). Considering only positive samples, $T$. cati appeared in $80 \%$ of samples, followed by Giardia sp. in $30 \%$ and Isospora sp. identified in $15 \%$. 
Table 3. Occurrence of enteroparasites (helminths and protozoa) and associations in feral cats found at FPZSP.

\begin{tabular}{ccc}
\hline Parasite & Positive samples & Prevalence (\%) \\
\hline Toxocara cati (helminth) & 16 & 59.26 \\
Giardia sp. (protozoa) & 6 & 22.22 \\
Isospora sp. (protozoa) & 3 & 11.11 \\
Associations & & \\
Toxocara cati + Giardia sp. & 4 & 14.81 \\
Toxocara cati + Isospora sp. & 2 & 7.41 \\
\hline
\end{tabular}

\section{Discussion}

\subsection{Captive Wild Felids}

The present study found a prevalence of parasitic infection in captive animals of $19.41 \%$. This prevalence was lower than has previously been reported in Brazil, with prevalence ranging from $20.2 \%$ to $64.3 \%$, and other studies conducted around the world, which reported infection rates between $36.7 \%$ and $89.3 \%$ [17] [18] [28] [29] [35] [38]. Although some studies included other Carnivora species, if only felids are considered, the prevalence is still higher than the one observed in the present study [17] [18] [28] [29] [35] [38]. This is probably due to the adoption of careful sanitary measures, including frequent cleaning of enclosures, removal of food debris and use of footbaths, all accepted preventive veterinary medicine techniques [35] [41].

The prevalence of helminth infections (16.63\%) in the present study was higher than that of protozoan (3.14\%), a fact also observed in zoos in Malaysia, Bangladesh and Italy [17] [28] [35].

Considering the coproparasitological profiles, $T$. cati was reported as one of the most common parasites in felids, not only in Brazil, but also around the world [38]. Our study corroborates that, with this being the parasite with the highest prevalence. This demonstrates the cosmopolitan characteristic of this parasite, the resistance of its eggs and its infective capacity [28] [35] [41] [42]. These infections were already observed in several reports [17] [27] [32] [35] [38]. The striking presence in lions $(P$. leo) confirms the findings in India and Italy [32] [35]. The results in the northern tiger (L. tigrinus) confirm the finding in Paraná (Brazil) [38]. The existence of T. leonina in bengal tiger (P. tigris tigris) differs from previous findings, where $T$. cati predominated [17] [28] [35]. The frequent presence of $T$. leonina in captive animals and absence in wild cats is frequently reported in the literature, a fact that could be explained by the difference of food offered to captive lions and the proximity of these animals to a great variety of other host species [30]. It is also known that the life cycle of this parasite greatly influences the persistence of infections since its eggs become infective on the soil in one week, facilitating the contamination of captive animals [42].

Isospora sp. was found in four species in a relatively low prevalence $(2.03 \%)$, 
when compared to another study realized in Paraná, Brazil, that was of $14.28 \%$ [38]. Despite the low prevalence, the presence of this parasite in captive animals may represent a risk, since stress or other infection may lead to development of main symptoms of isosporosis [43].

The low prevalence of $H$. nana (0.92\%), Eimeria sp. (0.37\%), Blastocystis sp. (0.37\%) and Ascaris sp. (0.18\%) found in this study corroborates with other studies [36]. Eimeria sp. was not reported as infecting felids, however some studies did not specify the coccidian genera found in their studies [17] [30]. Blastocystis sp. was found only in geoffroyi's cat ( $L$. geoffroyi), the literature reports the presence of this parasite only in primates [28]. Ascaris sp. was present only in bengal tiger (Panthera tigris tigris); this parasite has been reported to exhibit high prevalence in herbivores [18].

The prevalence of Giardia sp. (0.37\%) was low when the present study is compared to others [29] [30]. Presence of Giardia sp. was already reported in other zoos, mainly in Brazilian native species [29] [44].

Among the 13 captive species analyzed in this study, only four had negative results for all samples: ocelot (L. pardalis), jaguar ( $P$. onca), leopard ( $P$. pardus mela) and amur tiger ( $P$. tigris altaica). The small number of samples of ocelot and leopard could be one of the reasons for these findings. The results observed for jaguar are different from those found in other studies that report infections by helminths and protozoans [29] [38]. Amur tigers were already found to have parasite infections in eastern Russia [45].

Spirometra sp. is a common helminth in zoological animals, constantly found in felids and is considered the most frequent parasite in some studies [17] [28] [30] [31] [37] [38]. The absence of this cestode in samples from FPZSP could be attributed to the absence of intermediate hosts necessary for completing the parasite life cycle [17] [41].

The difference between coproparasitological profiles of native and exotic species is considerable regarding the number of parasite species and prevalence. Among native felids, seven parasite species were identified: T. cati (12.46\%), Isospora sp. (3.19\%) and Toxascaris leonina (1.74\%). Among the exotic felids, only three species were observed: T. leonina (17.86\%), H. nana (1.53\%) and $A s$ caris sp. (0.51\%). A similar occurrence was observed in Pomerode Zoo (Santa Catarina, Brazil), where all exotic felids were free of gastrointestinal parasite infections, while native species had infections by Giardia sp. and Trichuris sp. [29].

Although the parasite species infecting the two groups were different, infection rates were similar. Among the native samples, $19.13 \%$ were positive to parasites, compared to $19.9 \%$ of exotic species samples. In addition, helminths were the most frequent infections in both groups, representing $14.78 \%$ of native samples and $19.9 \%$ of exotic samples.

\subsection{Feral Cat (Felis catus)}

In the present study, an infection rate of $74.07 \%$ was observed in Felis catus 
samples, much higher than the prevalence reported for domiciled cats, where prevalence ranged from $31.5 \%$ to $56.8 \%$ [14] [15] [21] [24] [25]. However, it was lower when compared to the prevalence obtained by studies with wandering cats, that was of $87.9 \%$ and $100 \%$ [19] [24].

Multiple parasitism was observed in $22.22 \%$ of the samples, and association between T. cati and Giardia sp. was the most frequent. Previous studies in Rio de Janeiro (Brazil) reported associations between Ancylostoma sp. and Toxocara sp. in $32.8 \%$ of samples [24].

Considering the coproparasitological profile of these animals, three species were identified, a lower diversity than reported by other authors when six to nine species were identified [14] [15] [19] [21] [25].

In the present study, helminth $T$. cati was the most common, with a prevalence of 59.26\%; similar results were obtained in other cities in São Paulo state [19] [23]. However, there was a big difference from other studies with wandering and domiciled cats, in which $T$. cati appears with a prevalence ranging from $0.86 \%$ to $19.1 \%$ [14] [15] [20] [21] [24] [25]. One explanation for this low prevalence in domiciled animals is due to good nutrition and periodic antiparasitic treatment. The low values reported in other studies with wandering animals may reflect the lack of fixed habitat of these cats, since the eggs of $T$. cati need four weeks to reach the infecting stage, a time surpassing to the presence of the animals [42].

Despite other studies presenting greater infection by protozoa [21], in this study, Giardia sp. had a prevalence of $22.22 \%$ and is the second most prevalent parasite. Although there was a similar result in Botucatu (São Paulo, Brazil), a lower prevalence is commonly reported in the literature [15] [19] [21] [24] [25]. This parasite affects not only companion animals, but also other mammals, including humans. This parasite is considered to have zoonotic potential, causing severe enteritis, so understanding its distribution among animals that share the same environment with humans is essential for our health [38] [42].

While the present study reports a low prevalence of Isospora sp. (11.11\%), other studies found it to have higher prevalence between $45.3 \%-50.72 \%$, and being the most common parasite [23] [24] [25].

It is important to highlight the absence of Ancylostoma sp. in the studied population, a parasite commonly mentioned in studies with domestic cats [19] [24]. It is suggested that the absence of this parasite is due either to non-infection or the fact that cats are still not releasing eggs of hookworms in their feces.

Although the number of identified parasite species in the captive felids samples was higher than those of feral felids, the same parasites were found in both groups but in different prevalence. Toxocara cati had the highest prevalence in both feral and captive groups. Giardia sp. was the second most common parasite among feral cats (22.22\%), however its prevalence was significantly lower $(0.37 \%)$ in the captive group. Isospora sp. was the third most common in both captive and feral animals, but more frequent among feral cats than captive 
(11.11\% and $2.03 \%$, respectively). While these shared species are significant, their presence alone is not sufficient evidence to claim that feral cats are their reservoirs. As has been noted, past studies have shown that these parasites are frequently found in felids in general and all species have already been reported for both groups. While the existence of a proximally relevant transmission route between feral and captive felids is legitimate, it does not appear to be the predominant method by which captive felids are acquiring infection. This must, of course, be afforded additional studies and ideally, alternative sampling and analyzing methodologies. Indeed, the authors recognize that the absence of an active sampling methodology was a limitation of this study. Nonetheless, it is hoped the work has provided a foundation for what is needed, and adds to our understanding of the parasitic profile of these animals. Going forward, we also recognize the importance of maintaining control over the feral colonies living in the FPZSP area given their close contact with humans and the potential for disease spread within the community.

\section{Conclusions}

We were able to identify eight different parasite species infecting captive felids in FPZSP and three infecting feral cats. Toxocara cati was the most frequent parasite in both groups.

There was a considerable difference between the coproparasitological profile of exotic and native captive felids. We found there was both a greater diversity of parasites found in native felids than in exotic, along with major differences in the overall prevalence of parasite species among these two groups.

While our study found feral cats and captive felids to share many of the same parasite species, it is not possible to claim that those in the feral group act as a reservoir; we base this on the fact that the species identified are common felid parasites, found in all environments, along with the inability of our study to confirm direct link(s) of transmission between the two groups.

\section{Acknowledgements}

The authors thank the São Paulo Zoological Park Foundation for supporting this study.

\section{Conflicts of Interest}

The authors declare no conflicts of interest regarding the publication of this paper.

\section{References}

[1] Marino, L.M.R. (2008) Caracterização e zoneamento ambiental do zoológico municipal de Mogi Mirim, SP. Dissertation, Federal University of São Carlos.

[2] Sanders, S. and Feijó, A.G.S. (2007) Uma reflexão sobre animais selvagens cativos em zoológicos na sociedade atual. Congresso Internacional Transdisciplinar Ambiente. PUC-RS, Porto Alegre. 
[3] HISTÓRIA (2018) History of São Paulo Zoo Foundation.

http://www.zoologico.com.br/a-fundacao/historia

[4] QUEM SOMOS (2018) A Fundação Parque Zoológico de São Paulo.

http://www.zoologico.com.br/a-fundacao/quem-somos

[5] Carniatto, C.H.O., Jansen, J. and Fischer, M.L. (2011) É possível aplicar conceitos de bem-estar animal em felinos mantidos em zoológicos? Encontro Internacional De Produção Científica.

http://www.cesumar.br/prppge/pesquisa/epcc2011/anais/caio_henrique_oliveira_ca rniatto_1.pdf

[6] Carniatto, C.H.O., Rosa, V.M., Cavalaro, G.C., Azevedo, W. and Soares, C.S. (2011b) Comportamento e estresse em Leopardus pardalis e Puma yagouaroundii cativos. Encontro Internacional De Produção Científica.

http://www.cesumar.br/prppge/pesquisa/epcc2011/anais/caio_henrique_oliveira_ca rniatto_4.pdf

[7] Boorer, M. (1982) Felinos. Melhoramentos, São Paulo.

[8] Silva, D.C. and Sarapicos, E.O. (2009) Enriquecimento ambiental com duas espécies de Felídeos cativos do gênero Panthera (Oken, 1816). Congresso de Iniciação. Unisa, São Paulo. http://www.unisa.br/pesquisa/arquivos/livro_12_congresso.pdf

[9] Montes, G.A. and Byk, J. (2011) A influência do enriquecimento ambiental no comportamento de leões, Panthera leo (Felidae Linnaeus, 1758) no Zoológico Municipal de Uberlândia MG. Seminário de Iniciação Científica, VI Jornada de Pesquisa de Pós-Graduação e Semana Nacional de Ciência e Tecnologia.

http://www.prp.ueg.br/sic2011/apresentacao/trabalhos/pdf/ciencias_biologicas/sic/c b_sic_a_influencia_do_\%20enriquecimento.pdf

[10] Carniatto, C.H.O., Babá, A.Y. and Rosado, F.R. (2009) Enriquecimento ambiental com felinos em cativeiro do Parque do Ingá. Encontro Internacional De Produção Científica CESUMAR.

http://www.cesumar.br/epcc2009/anais/caio_henrique_oliveira_carniatto.pdf

[11] Moreira, N. (2001) Reprodução e estresse em fêmeas de felídeos do gênero Leopardus. Dissertation, Federal University of Paraná.

[12] IUCN (2018) The IUCN Red List of Threatened Species. Version 2014.2. http://www.iucnredlist.org

[13] Rivetti Junior, A.V. (2006) Retroviroses, Toxoplasma gondii e Mycoplasma haemofelis em gatos errantes e felinos selvagens do Zoológico de Belo Horizonte. Dissertation, Federal University of Minas Gerais.

[14] Dall'agnol, L.P., Otto, M.A., Silva, A.S. and Monteiro, S.G. (2010) Parasitos gastrintestinais em gatos naturalmente infectados no município de Santa Maria no estado do Rio Grande do Sul, Brasil. Acta Veterinaria Brasilica, 4, 181-184.

[15] Ferreira, F.P., Dias, R.C.F. and Martins, T.A. (2013) Frequência de parasitas gastrointestinais em cães e gatos do município de Londrina, $\mathrm{PR}$, com enfoque em saúde pública. Semina: Ciências Agrárias, 34, 3851-3858.

https://doi.org/10.5433/1679-0359.2013v34n6Supl2p3851

[16] Mendes-de-Almeida, F., Faria, M.C.F., Branco, A.S., Serrão, M.L., Souza, A.M., Almosny, N., Charme, M. and Labarthe, M. (2004) Sanitary Conditions of a Colony of Urban Feral Cats (Felis catus Linnaeus, 1758) in a Zoological Garden of Rio de Janeiro, Brazil. The Revista do Instituto de Medicina Tropical de São Paulo, 46, 269-274. https://doi.org/10.1590/S0036-46652004000500007

[17] Raja, M.M.R.U., Dey, A.R., Begum, N., Kundu, U.K. and Ashad, F.A. (2014) Coprological Prevalence of Gastrointestinal Parasites in Carnivores and Small Mammals 
at Dhaka Zoo, Bangladesh. Journal of Threatened Taxa, 6, 5574-5579. https://doi.org/10.11609/JoTT.o3569.5574-9

[18] Thawait, V.K., Maiti, S.K. and Dixit, A.A. (2014) Prevalence of Gastro-Intestinal Parasites in Captive Wild Animals of Nadan Van Zoo, Raipur, Chhattisgarh. Veterinary World, 7, 448-451. https://doi.org/10.14202/vetworld.2014.448-451

[19] Coelho, W.M.D. (2009) Ocorrência de parasitos gastrintestinais em amostras fecais de felinos no município de Andradina, São Paulo. The Revista Brasileira de Parasitologia Veterinária, 18, 46-49. https://doi.org/10.4322/rbpv.01802010

[20] Cortês, V.A. (1988) Infestação por ancilostomídeos e toxocarídeos em cães e gatos apreendidos em vias públicas, São Paulo (Brasil). Revista de Saúde Pública, 22, 341-343. https://doi.org/10.1590/S0034-89101988000400010

[21] Funada, M.R., Pena, H.F.J., Soares, R.M., Amaku, M. and Gennari, S.M. (2007) Freqüência de parasitos gastrintestinais em cães e gatos atendidos em hospital-escola veterinário da cidade de São Paulo. Arquivo Brasileiro de Medicina Veterinária e Zootecnia, 59, 1338-1340. https://doi.org/10.1590/S0102-09352007000500038

[22] Mendes-de-Almeida, F., Silva, M.M.O. and Labarthe, N. (2007) Giardia spp. em amostras fecais de gatos domésticos do Rio de Janeiro, RJ. Acta Scientiae Veterinariae, 35, 468-469.

[23] Ragozo, A.M.A., Muradian, V., Ramos e Silva, J.C., Caravieri, R., Amajoner, V.R., Magnabosco, C. and Gennari, S.M. (2002) Ocorrência de parasitos gastrintestinais em fezes de gatos das cidades de São Paulo e Guarulhos. Brazilian Journal of Veterinary Research and Animal Science, 39, 244-246. https://doi.org/10.1590/S1413-95962002000500005

[24] Serra, C.M.B., Uchôa, C.M.A. and Coimbra, R.A. (2003) Exame parasitológico de fezes de gatos (Felis catus domesticus) domiciliados e errantes da região metropolitana do Rio de Janeiro, Brasil. Revista da Sociedade Brasileira de Medicina Tropical, 36, 331-334. https://doi.org/10.1590/S0037-86822003000300003

[25] Torrico, K.J., Santos, K.K., Martins, T., Paz e Silva, F.M., Takahira, R.K. and Lopes, R.S. (2008) Ocorrência de parasitas gastrintestinais em cães em gatos na rotina do laboratório de enfermidades parasitárias da FMVZ/UNESP-Botucatu, SP. The Revista Brasileira de Parasitologia Veterinária, 17, 182-183.

[26] Despommier, D. (2003) Toxocariasis: Clinical Aspects, Epidemiology, Medical Ecology and Molecular Aspects. Clinical Microbiology Reviews, 16, 265-272. https://doi.org/10.1128/CMR.16.2.265-272.2003

[27] Freitas, M.F.L., Oliveira, J.B., Cavalcanti, M.D.B., Oliveira, R.A. and Sobrinho, A.E. (2001) Perfil coproparasitológico de mamíferos silvestres em cautiverio en el estado de Pernambuco, Brasil. Parasitología al día, 25, 121-125.

https://doi.org/10.4067/S0716-07202001000300009

[28] Lim, Y.A.L., Nguim, R., Shukri, J., Rohela, M. and Mat Naim, H.R. (2008) Intestinal Parasites in Various Animals at a Zoo in Malaysia. Veterinary Parasitology, 157, 154-159. https://doi.org/10.1016/j.vetpar.2008.07.015

[29] Müller, G.C.K., Greinert, J.A. and Silva Filho, H.H. (2005) Freqüência de parasitas intestinais em felinos mantidos em zoológicos. Arquivo Brasileiro de Medicina Veterinária e Zootecnia, 57, 559-561. https://doi.org/10.1590/S0102-09352005000400021

[30] Muller-Graf, C.D.M. (1995) A Coprological Survey of Intestinal Parasites of Wild Lions (Panthera leo) in the Serengeti and the Ngorongoro Crater, Tanzania, East Africa. Journal of Parasitology, 81, 812-814. https://doi.org/10.2307/3283987

[31] Parsani, H.R., Momin, R.R., Maradia, M.G. and Singh, V. (2001) A Survey of Gas- 
tro-Intestinal Parasites of Captive Animals at Rajkot Municipal Coorporation Zoo, Rajkot, Gujarat. Zoos' Print Journal, 16, 604-606. https://doi.org/10.11609/JoTT.ZPJ.16.10.604-6

[32] Ravidran, R., Lakshmanan, B., Anoop, S., Rajeev, T.S. and Dinesh, C.N. (2006) Parasitic Infection in Captive Lions (Panthera leo) at Wayanad. Zoos' Print Journal, 21, 2230. https://doi.org/10.11609/JoTT.ZPJ.1438.2230

[33] Esfandiari, B., Youssefi, M.R. and Tabari, M.A. (2010) First Report of Toxocara cati in Persian Leopard (Panthera pardus saxicolor) in Iran. Global Veterinaria, 4, 394-395.

[34] Ghaemi, P., Sadr-Shirazi, N. and Ghaemi, P. (2011) Study on Helminthic Parasites of Persian Leopardo (Panthera pardus saxicolor Pocock, 1927) in Golestan National Park and Biosphere Reserve of Iran. World Applied Sciences Journal, 13, 1471-1473.

[35] Fagiolini, M., Lia, R.P., Laricchiuta, P., Cavicchio, P., Mannella, R., Cafarchia, C., Otranto, D., Finotello, R. and Perrucci, S. (2010) Gastrointestinal Parasites in Mammals of Two Italian Zoological Gardens. Journal of Zoo and Wildlife Medicine, 41, 662-670. https://doi.org/10.1638/2010-0049.1

[36] Acosta, L., León-Quinto, T., Bornay-Llinares, F.J., Simón, M.A. and Esteban, J.G. (2011) Helminth Parasites in Faecal Samples from the Endangered Iberian Lynx (Lynx pardinus). Veterinary Parasitology, 179, 175-179. https://doi.org/10.1016/j.vetpar.2011.01.058

[37] Berentsen, A.R., Becker, M.S., Stockdale-Walden, H., Matandiko, W., McRobb, R. and Dunbar, M.R. (2012) Survey of Gastrointestinal Parasite Infection in African Lion (Panthera leo), African Wild Dog (Lycaon pictus) and Spotted Hyaena (Crocuta crocuta) in the Luangwa Valley, Zambia. African Zoology, 47, 363-368. https://doi.org/10.1080/15627020.2012.11407561

[38] Moreira, L.H.A., Yamada, F.H., Ceschini, T.L., Takemoto, R.M. and Pinto, C.J.C. (2009) Study of Gastrointestinal Parasites in Felines from Itaipu Binacional Wild Animal Nursery, Brazil. Arquivos de Ciências Veterinárias e Zoologia da UNIPAR, 12, 11-15.

[39] Hendrix, C.M. and Robinson, E. (2006) Parasitology Diagnostic for Veterinary Technicians. 3rd Edition, Mosby Elsevier, St. Louis.

[40] Foreyt, W. (2005) Veterinary Parasitology Reference Manual. 5th Edition, Iowa State University Press, Ames.

[41] Castro, J.M. (1999) Ocorrência de parasitos em felídeos de zoológicos do estado de Minas Gerais Brasil. Seminário Brasileiro De Parasitologia Veterinária. 11, 181.

[42] Georgi, J.R. (1982) Parasitologia veterinária. Interamericana, Rio de Janeiro.

[43] Vasconcelos, M.G.C., Talon, D.D.B., Silva Junior, C.A., Neves, M.F. and Sacco, S.R. (2008) Isosporose nos animais domésticos. Revista Científica Eletrônica de Medicina Veterinária, 10, 1-7.

[44] Acosta, M.Z., Tantaleán, M.V. and Serrano-Martínez, E. (2015) Identificación de parasitos gastrointestinales por coproscopía en carnívoros Silvestres del Zoológico Parque de las Leyendas, Lima, Perú. Revista de Investigaciones Veterinarias del Peru, 26, 282-290. https://doi.org/10.15381/rivep.v26i2.11000

[45] González, P., Carbonell, E., Urios, V. and Rozhnov, V.V. (2007) Coprology of Panthera tigris Altaica and Felis bengalensis euptilurus from the Russian Far East. Journal of Parasitology, 93, 948-950. https://doi.org/10.1645/GE-3519RN.1 